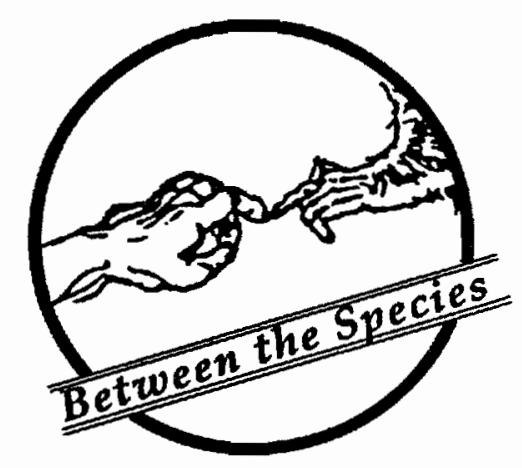

\title{
MUSLIM PRAYER SERVICE: Quotations and a Tradition World Week of Prayer for Animals
}

\section{Rev. Dr. Marc A. Wessels \\ International Network for Animals and Religion}

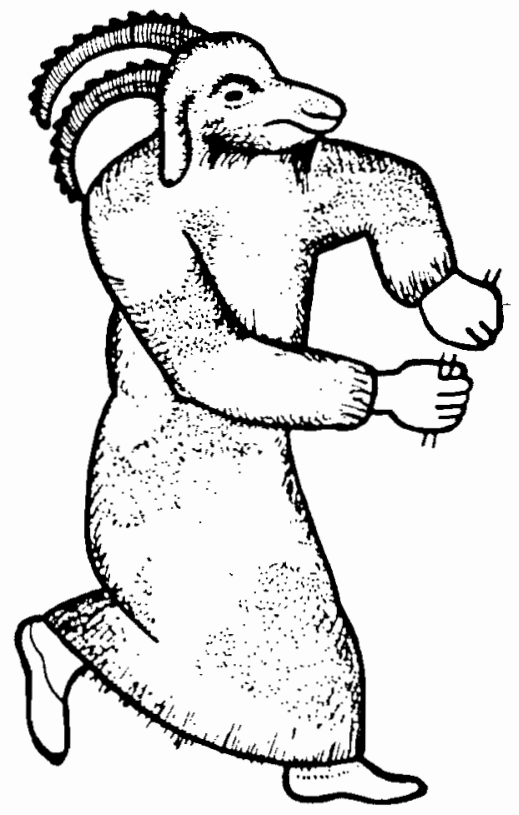

\section{Quotations}

"There is no man who kills (even) a sparrow or anything smaller, without its deserving it, but God will question him about it. He who takes pity (even) on a sparrow and spares its life, Allah will be merciful on him on the Day of Judgement."

"The Holy Prophet Muhammad(s) was asked by his companions if kindness to animals was rewarded in the life hereafter. He replied: "Yes, there is meritorious reward for kindness to every living creature.'"

"The Holy Prophet(s) once passed by a camel who was so emaciated that his belly had shrunk to his back. He said to the owner of the camel, 'Fear God in these dumb animals and ride them only when they are fit to be ridden, free them from work while they are still in good health.' "

"Whoever is kind to the lesser creatures is kind to himself." - Prophet Muhammad

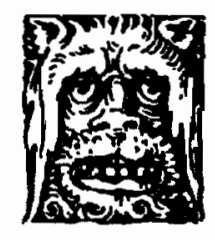

\section{RELIGION}


"There is not an animal on the earth, nor a flying creature flying on two wings, but they are peoples like unto you." - Koran, surah 6, verse 38

"...but to hunt...is forbidden you, so long as ye are on the pilgrimage. Be mindful of your duty to Allah, unto Whom you will all be gathered." Koran, surah 5, verse 96

“The Prophet(s) told his companions of a woman who would be sent to Hell for having locked up a cat; not feeding it, not even releasing it so that it could feed herself."

"The Prophet told his companions of a serf who was blessed by Allah for saving the life of a dog by giving it water to drink and quenching its thirst."

"The Prophet was asked if acts of charity even to the animals were regarded by God. He replied: 'Yes, there is a reward for acts of charity to every beast alive." "

"The Prophet(s) was seen wiping the face of his horse with his gown (jullabiyah). When asked why he was doing that, he replied: 'Last night I had a reprimand from Allah regarding my horse for having neglected him.' "

\section{The Sufi Tradition}

There is an ancient story about a woman Sufi saint, Hazrat Rabia Basri, who would regularly go to a particular mountain in the forest in order to meditate in perfect tranquility. When she would go, all the animals of the forest would come near to enjoy her good company. One day, another Sufi arrived. But as soon as he approached, all the animals ran away, as if in fear. Completely vexed, the Sufi inquired of Rabia Basri, "Why do the animals run?"

Rabia countered with another question: "What have you eaten today?" The Sufi confessed that he had eaten an onion fried in some fat. The wise Sufi woman concluded: "You eat their fat! Why should they not flee from you?" This famous Sufi tale is perhaps indicative of the Islamic mystical perspective on human-animal interrelations. ${ }^{2}$

\section{$\underline{\text { Notes }}$}

1 Unless otherwise indicated, all quotes are taken from "Islamic Concern for Animals," by Al-Hafiz B. A. Masri, Athene Trust, 3A Charles Street, Petersfield, Hampshire, England.

2 Taken from "Food for the Spirit," by Steven Rosen, Bala Books, New York.

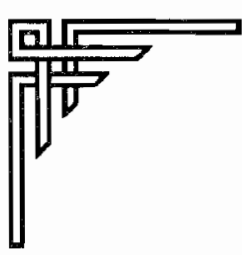

\section{Epitaph}

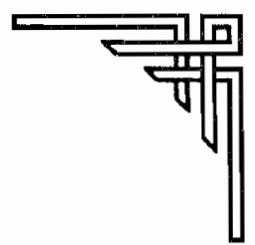

How can we mourn over

That which we never knew?

The giant chestnut trees

The salmon runs, the song of the wolf, Otter pools and the jewelled flicker Of dragonflies.

The sun-greeting of the lemurs

Wild, free rivers and sacred mountains

Medicine wheels and mandalas.

\section{Is it thus}

That we will adapt?

Shells of extinct passion

Choosing to love

Only what is available.

Knowing only silent Springs

We yearn for nothing more.

Is that what saves us

From suicide?

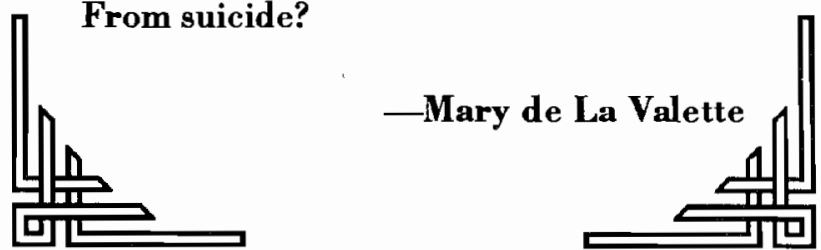

